Brit. J. vener. Dis. (1966), 42, 40.

\title{
AGEING AND FALSE POSITIVE REACTIONS FOR SYPHILIS*
}

\author{
BY \\ DENNY L. TUFFANELLI \\ Division of Dermatology, Department of Medicine, University of California School of Medicine, \\ San Francisco, California 94122
}

Biological false positive reactors for syphilis (BFP) are defined as those patients having reagin demonstrated by positive serological tests for syphilis and non-reactive treponemal antibody tests. Acute biological false-positive reactions (ABFP) terminate in 1 to 6 months. Patients in whom reagin persists longer than 6 months are considered to have chronic reactions (CBFP). Harvey (1962) stressed the high incidence of autoimmune diseases in patients with CBFP reaction, particularly in females. Burch and Rowell (1963) suggested that many aspects of ageing are fundamentally autoimmune in character. The purpose of this paper is to report our studies of the incidence of chronic biological false-positive reactors in an aged population group.

\section{Subjects and Methods}

Sera were obtained from 58 aged persons randomly selected in a Jewish old age home, thirteen healthy but aged patients with CBFP reactions, and 71 healthy normal subjects aged 14 to 50 years. Blood was drawn by venepuncture for the following studies: venereal disease research laboratory tests (VDRL), Kolmer, Treponema pallidum immobilization test, fluorescent treponemal antibody absorption test, LE-cell preparation, latex fixation for rheumatoid factor, antinuclear antibody determination, paper electrophoresis, and in some instances immuno-electrophoresis. Serological tests for syphilis were carried out by the California State Department of Public Health. LE-cell preparations were made by the rotary technique of Dubois and Freeman (1957). The fluorescent antinuclear antibody technique of Coons and Kaplan (1950) modified by Vazquez and Dixon (1956) was applied. Rheumatoid factor and thyroglobulin auto-antibody were studied by latex fixation (Hyland). Immuno-electrophoresis was performed by the technique of Scheidegger (1955).

\section{Results}

Six of the 58 randomly selected aged persons (9 per cent.) had persistently positive reagin tests for syphilis. Treponemal antibodies were not found, and by definition these patients had CBFP reactions. Additionally, thirteen of 62 patients studied in a clinic for CBFP reactors had developed Wassermann reagin after the age of 60 and had no known cause for the onset of the CBFP reaction. Thus nineteen patients

\footnotetext{
- Received for publication July 6, 1965.
}

were studied in whom ageing was associated with the development of reagin.

The age incidence of the total of 71 aged patients studied is listed in Table $\mathrm{I}$. In addition to reagin there was a significant incidence of autoantibodies directed toward normal tissues in the aged group studied.

TABLE I

AGE OF PATIENTS STUDIED

\begin{tabular}{c|c}
\hline Age (yrs) & Number of Patients \\
\hline $60-65$ & 3 \\
$66-70$ & 5 \\
$71-75$ & 7 \\
$76-80$ & 15 \\
$81-85$ & 23 \\
$86-90$ & 12 \\
$91-95$ & 6 \\
\hline
\end{tabular}

These included antinuclear antibodies in 22 patients (31 per cent.) and rheumatoid factor in 24 (32 per cent.). LE factor and thyroglobulin antibodies were not noted. Serum electrophoresis also demonstrated a significant incidence of abnormalities. Alpha globulin were raised in thirteen patients (18 per cent.) and beta globulin in ten (14 per cent.), and there was hypergammaglobulinaemia in 24 (34 per cent.). No abnormalities were noted in the immuno-electrophoretic pattern of twelve patients studied. The data are listed in Table II.

TABLE II

RESULTS OF SERUM STUDIES ON 71 AGED PERSONS AND 71 CONTROLS

\begin{tabular}{|c|c|c|c|c|c|c|}
\hline \multirow{2}{*}{\multicolumn{3}{|c|}{ Tests }} & \multicolumn{3}{|c|}{ Aged Persons } & \multirow{2}{*}{$\begin{array}{c}\text { Control } \\
\text { Group }\end{array}$} \\
\hline & & & VDRL + & VDRL - & Total & \\
\hline \multicolumn{3}{|c|}{ Antinuclear Antibody } & 7 & 15 & 22 & 4 \\
\hline \multicolumn{2}{|c|}{ Rheumatoid Factor } & $\cdots$ & 6 & 18 & 24 & 3 \\
\hline \multicolumn{2}{|l|}{ LE Factor } & $\cdots$ & 0 & 0 & 0 & 0 \\
\hline \multicolumn{2}{|c|}{ Thyroglobulin Antibody } & $\cdots$ & $\mathbf{0}$ & 0 & 0 & 0 \\
\hline \multicolumn{2}{|c|}{ Albumin Decreased } & $\cdots$ & 2 & 2 & 4 & 4 \\
\hline $\begin{array}{l}\text { Globulin } \\
\text { Increased }\end{array}$ & \multicolumn{2}{|c|}{$\begin{array}{l}\text { Alpha }_{1} \\
\text { Alpha } \\
\text { Beta } \\
\text { Gamma }\end{array}$} & $\begin{array}{l}2 \\
6 \\
6 \\
6\end{array}$ & $\begin{array}{r}2 \\
7 \\
4 \\
18\end{array}$ & $\begin{array}{r}4 \\
13 \\
10 \\
24\end{array}$ & $\begin{array}{l}3 \\
5 \\
4 \\
7\end{array}$ \\
\hline \multicolumn{3}{|c|}{ Total No. of Tests } & 19 & 52 & 71 & 71 \\
\hline
\end{tabular}




\section{Discussion}

An increased incidence of abnormal circulating proteins in the aged has been reported by several workers. Cammarata, Rodnan, Fennell, Cestello, and Creighton (1964) studied 325 patients aged 70 years or more. 52 (16 per cent.) had a positive latex agglutination test with titres of $1: 160$ or greater in twenty cases, and 93 of 255 (37 per cent.) had antinuclear antibodies as detected by an indirect immunohistochemical method. Gamma globulins were slightly greater in the aged groups (average $1 \cdot 15 \mathrm{~g}$. per cent.) compared with a younger control group (average $0.96 \mathrm{~g}$. per cent.).

In an aged population (average age 72 years), Litwin and Singer (1963) found latex fixation or F-11 sheep red cell tests positive in significant titre in 32 per cent., haemagglutination tests for antibodies to thyroglobulin in 20 per cent., and the VDRL test reactive in 22 per cent. of those tested.

Heimer, Levin, and Rudd (1963) found globulins resembling rheumatoid factor in 46 per cent. of 171 aged persons. They suggested that ageing may represent a breakdown in the mechanism which normally prevents lymphocytes from producing antibodies against body components.

In an institutionalized geriatric population studied by Bach, Grieble, and Anderson (1965), dysproteinaemia was found in 55 per cent. of 231 patients studied, rheumatoid factor was present in 42 per cent., and 11 per cent. had biological false-positive tests for syphilis.

Dixon, Vazquez, Weigle, and Cochrane (1959) have suggested that poor antibody formers produce abnormal proteins. LoSpalluto (1963) found a low antibody response to paratyphoid immunization in the elderly. Gross (1965) studied the delayed hypersensitivity response to dinitrochlorobenzene and found a drop in the response rate to 62 per cent. in an older age group from 96.7 per cent. in a control group aged 13 to 17 years.

Wassermann reagin may be present in the serum briefly during pregnancy and unrelated nonspecific infections, and persistent biological falsepositive reactions may be noted with autoimmune disorders, hypergammaglobulinaemia, atopic states, cancer, and cirrhosis, but ageing per se has not previously been listed as a cause of such reactions.

A multitude of other autoantibodies have been noted in aged persons. The increased incidence of abnormal circulating proteins (including antinuclear antibodies, rheumatoid factor, and hypergammaglobulinaemia) noted in our series is similar to that reported by others. Similarly the production of reagin may also be related to the ageing process.

\section{Summary}

(1) Six of 58 randomly studied aged persons (average age 82 years) had chronic biological falsepositive (CBFP) reactions for syphilis.

(2) Thirteen of 62 patients with CBFP reactions had developed reagin after the age of 60 .

(3) Of 71 aged persons studied 22 (31 per cent.) showed antinuclear antibody, 24 (32 per cent.) rheumatoid factor, and 24 (34 per cent.) hypergammaglobulinaemia.

(4) Ageing per se may result in a CBFP reaction for syphilis.

This investigation was supported in part by a University of California School of Medicine Committee on Research Grant No. 09 Breon Fund, and in part by a PHS Research Grant No. 1 RO1 ATO6609 from the Bacteriology and Mycology Branch of the National Institute of Allergy and Infectious Diseases, US Public Health Service.

\section{REFERENCES}

Bach, G. L., Grieble, H. G., and Anderson, T. O. (1965). Clin. Res. (Abstr.), 13, 284.

Burch, P. R. J., and Rowell, N. R. (1963). Lancet, 2, 507.

Cammarata, R. J., Rodnan, G. P., Fennell, R. H., Cestello, R. J., and Creighton, A. S. (1964). Arthr. and Rheum. (Abstr.), 7, 297.

Coons, A.H., and Kaplan, M.H.(1950).J.exp.Med.,91,1.

Dixon, F. J., Vazquez, J., Weigle, W. O., and Cochrane, C. G. (1959). "Immunology and Pathogenesis of Experimental Serum Sickness", in "Cellular and Humoral Aspects of the Hypersensitive States", ed. H. S. Lawrence, pp. 354-371. Hoeber, New York.

Dubois, E. L., and Freeman, V. (1957). Blood, 12, 657.

Gross, L. (1965). Cancer, 18, 201.

Harvey, A. M. (1962). J. Amer. med. Ass., 182, 513.

Heimer, R., Levin, F. M., and Rudd, E. (1963). Amer. J. Med., 35, 175.

Litwin, S. D., and Singer, J. M. (1963). Arthr. and Rheum. (Abstr.), 6, 782 .

LoSpalluto, J.' (1963). Ibid., 6, 487.

Scheidegger, J. J. (1955). Int. Arch. Allergy, 7, 103.

Vazquez, J. J., and Dixon, F. J. (1956). J.exp. Med., 104, 727.

Le vieillissement et les réactions pseudo-positives

$$
\text { de la syphilis }
$$

RÉSUMÉ

(1) 6 des 58 vieillards choisis au hasard ont été étudiés (ils étaient âgés, en moyenne, de 82 ans) et leurs réactions ont montré des réactions chroniques biologiques et pseudo-positives de la syphilis (CBPP).

(2) 13 des 62 malades donnant des réactions (CBPP) avaient développé de la réagine après l'âge de 60 ans.

(3) Des 71 vieillards étudiés, 22 (31 pour-cent) ont montré des anticorps antinucléaires, 24 (32 pour-cent) le facteur de polyarthrite, et 25 (34 pour-cent) l'hypergammaglobulinémie.

(4) Le vieillissement per se peut donner des réactions CBPP de la syphilis. 